\title{
Indledning. Jørgen Bæk Simonsen 70 år
}

Dette temanummer af Babylon er dedikeret til historikeren og Mellemøstforskeren JøRGEN BÆK SIMONSEN, som den 16. oktober fylder 70 år. I nordisk sammenhæng er Jørgen nok relativt ukendt, og han har typisk ikke deltaget i det Nordiske Selskab for Mellemøst-studiers konferencer. I Danmark er Jørgen derimod landskendt som en af de mest fremtrædende sagkyndige på Mellem$\emptyset$ sten og islam gennem tre årtier. Det har somme tider været en utaknemlig rolle. Derfor er vi særligt glade for at hylde ham her.

Som man endnu kan høre på dialekten, er Jørgen opvokset på Fyn, hvor faderen havde et gartneri. I 1973 indskrev han sig på historiestudiet ved Københavns Universitet. Det var i brydningstiden efter 1968, hvor professorvældet var ophørt og marxismen havde vundet indpas - uden dog at være enerådende. Mange af de studerende og enkelte af lærerne ville bryde med det klassiske positivistiske metodefag og inddrage nye områder i historiefaget. En af disse udviklinger var en voksende interesse for ikke-europæisk historie. Jørgen havde været i Israel og rejst i Mellemøsten og blev, som mange andre efter ham, optaget af regionens historie og kultur - både den nyere og den ældre - og måtte ved siden af historiestudierne begynde at lære sproget arabisk. Da han i $1979 \mathrm{blev}$ kandidat, udgav han samtidigt sin første videnskabelige artikel (i Historisk Tidsskrift), om de arabiske kilder til vikingetidens historie. Det er en oversigt over de arabiske kilder og en kritisk gennemgang af de hidtidige udgivelser af dem, af blandt andre Harris Birkeland og Stig Wikander. Jørgen fulgte op med sit eget bidrag, og i 1981 udkom hans første lille bog om Ibn Fadlans rejse- beskrivelse, med resume, delvis oversættelse og kommentar.

Denne interesse for kilder har været et bærende element i Jørgens forskning, men også i hans undervisning i klassisk islam, som har centreret sig om læsning af kilder i oversættelse.

Kildespørgsmålet er navnligt i centrum for hans mest ambitiøse arbejde, disputatsen Studies in the Genesis and Early Development of the Caliphal Taxation System with Special References to Circumstances in the Arab Peninsula, Egypt and Palestine (København: Akademisk forlag, 1988). Kristian Erslev, grundlæggeren af den historiske metodeundervisning i København gjorde meget ud af at skelne mellem levn og beretninger, altså mellem på den ene side faktiske konkrete genstande og udsagn, f.eks. indskrifter, og på den anden side sam- og eftertidens narrative bearbejdelse af historien. I studiet af arabisk historie havde man siden 1700tallets oversættelser af de arabiske historikere nogenlunde forladt sig på deres kronologi og forklaringer, altså beretninger, først og fremmest af mangel på levn. I begyndelsen af det 20. århundrede var imidlertid en del papyri dukket op med skattelister - altså egentlige levn, der muliggjorde en sammenligning med, hvad de arabiske historikere og jurister havde skrevet om beskatning. Denne diskussion havde professoren i semitisk filologi, Frede Løkkegaard, taget op i sin doktorafhandling, Islamic Taxation in the Classical Period with Special References to Circumstances in Iraq (København, 1950). Som undertitlerne illustrerer, er de to værker beslægtede. Men Jørgen flyttede fokus til Palæstina og særligt Egypten, og til perioden forud for den abbasidiske revolution. 


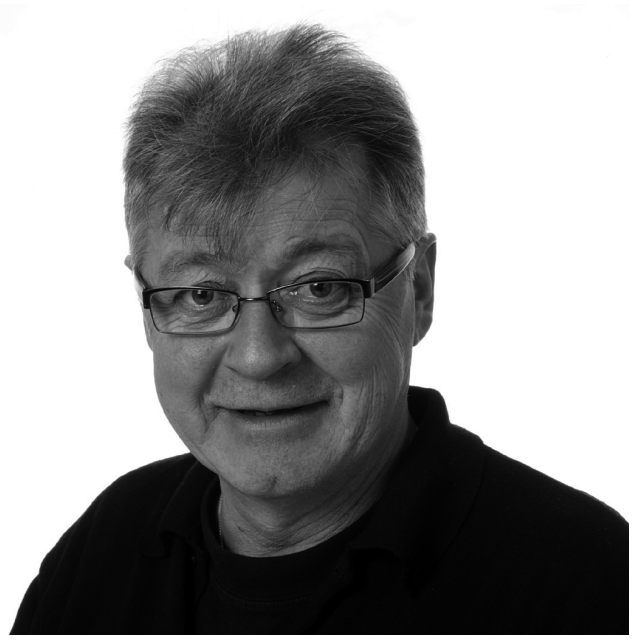

Der var også andre forskelle; hvor Løkkegaard var filolog, var Jørgen historiker. Og ind imellem de to stod den mere radikale skepsis over for de arabiske historikere, som navnlig Patricia Crone og Michael Cook nu havde fremlagt. Jørgen havde ikke nået at medtage Crones Meccan Trade, der søger at påvise farerne ved at skrive en $\emptyset$ konomisk historie baseret på de arabiske historikeres fremstilling af Mekka som et centrum for karavanehandlen. Men han delte hendes skepsis og hendes metodiske arbejde med at sætte levnene i forgrunden som en korrektion af en historiografi baseret på beretningerne. I de tidlige papyri optræder de ord for bytte og beskatning, man kender fra historikerne og de juridiske værker, fay', kharaj,jizya, khums. Men som han påviste, har de en anden $\emptyset$ konomisk og administrativ betydning $\mathrm{i}$ områderne, hvor det vedbliver at være de lokale, der inddriver den, typisk mere på basis af ældre, kollektive beskatninger.
Jørgen var perioden i 1981-84 ansat på Odense Universitet, hvor han var medstifter af Center for Mellemøst-studier, som i modsætning til de filologiske institutter i København og Aarhus skulle koncentrere sig om det nutidige Mellemøsten og i et mere samfundsmæssigt perspektiv og nok også i højere grad tjene et dansk publikum. Så nu fulgte publikationer om Den libanesiske borgerkrig (1983) og Arbejderbevagelsen $i$ Nordafrika-fra national uafhangighedskamptilstatslig afhangighed (1987). 1986-88 var han med i en bredere gruppe af forskere, der fik forskningsmidler fra Statens Humanistiske Forskningsråd til at studere islam i nutiden. Jørgen gennemførte her en undersøgelse af, hvordan muslimske indvandrere i Danmark havde organiseret sig religiøst og blev på den måde den første, som dannede sig et overblik over et nyt og voksende felt, som han samtidigt fik gode personlige forbindelser til. Dette nye forskningsområde resulterede i bogen Islam i Danmark (1990) og i de næste mange år blev Jørgen mediernes go-to person i spørgsmål vedrørende muslimer i Danmark.

Fra 1989 blev Jørgen stipendiat på Historisk Institut på Københavns Universitet, og i 1992 blev han ansat som lektor på Institut for Orientalsk Filologi. Dette institut blev i de år omskabt til Carsten Niebuhr Instituttet, som bibeholdt den stærke vægt på nærorientalske sprog i oldtid og nutid, men samtidigt supplerede den filologiske metode med andre humanistiske og samfundsfaglige discipliner. Jørgen spillede en væsentlig rolle i denne transformation, også som studieleder og senere institutleder 1996-2001. Siden har instituttet gennem sammenlægninger fået et nyt navn, 
Institut for Tværkulturelle og Regionale Studier. I midten af 1990’erne blev Jørgen leder af et forskningsnetværk, støttet af Forskningsrådet. Netværket hed «Kulturmøde. Mellemøsten. Religion, Historie og Samfund». I de år (1995-98) blev der med udgangspunkt på Carsten Niebuhr Instituttet afholdt en lang række internationale seminarer og forelæsninger om nogle af tidens varmeste forskningsemner; som for eksempel $k ø n$, civilsamfundets rolle i den politiske transformation og samspillet mellem islam og Vesten. Jørgen spillede også en afgørende rolle for at instituttet på dette tidspunkt fik et mere internationalt pust, da flere udenlandske gæste-professorer, som for eksempel Ahmad Moussali fra AUB og Michael Hudson fra Georgetown University, fik sin vante gang på Amager igennem flere år, til stor inspiration for instituttets efterhånden mange studerende.

Igennem alle årene har Jørgen undervist i Mellemøstens historie og beslægtede fag. Og det er som underviser, at mange bedst vil huske ham. Flere tusinde studerende har stiftet bekendtskab med Jørgen gennem årene. Som lærer var - og er han dynamisk og engageret, ja nærmest en performer. Samtidigt med at han år efter år husker de studerendes navne og udviser en ægte interesse for dem. Jørgen har den særlige evne, at han er i stand til at se de studerende i øjenhøjde, hvilket har skabt grobund for mange særlige og tætte bånd. Ikke mindst hans forelæsninger på det allerførste semester har fået mange til at føle, ikke bare at faget var vedkommende, men at de selv var velkomne og hørte til på universitetet. Til trods for helt fantastisk lange indskudte sætninger er
Jørgen en fremragende formidler. Han er i kraft af sin store viden om hele regionen i stand til at gøre nye håbefulde studerende interesseret i områder og aspekter af Mellemøstens moderne historie og samfundsforhold, som er både tankevækkende og inspirerende, og som har givet de studerende mod på at tænke højt og nyt, og brænde yderligere for deres studie. På den baggrund er det ikke overraskende, at Jørgen igennem årene været den mest søgte vejleder på faget. Mange af dette temanummers bidragydere har udtrykt glæde ved at få lov til at skrive en artikel her, netop fordi det var et festskrift til deres tidligere vejleder og for manges vedkommende mentor.

Det var ikke kun på instituttet at Jørgen gjorde brug af sit formidlingstalent. Igennem mange år har han optrådt på biblioteker, forsamlingshuse, foreninger, kirker, højskoler mm, hvor han har forelæst om emner, der ligesom hans forskning spænder meget vidt. Jørgen ser det som en forskers forpligtigelse at komme ud til bredere grupper i samfundet, og har inspireret denne tilgang til utallige af sine studerende gennem årene. Det er ikke for meget at sige at Jørgen har spillet en helt central rolle, også når det gælder bredere grupper af danskernes forståelse for ikke bare islam i Danmark, men også væsentlige aspekter af det moderne Mellemøsten.

Som national autoritet på feltet islam forsatte Jørgen sin forfattervirksomhed, som ligeledes sigtede mod et bredt publikum, med Politikens Islamleksikon (1994, 2. udg. 2001), Hvad er islam (2006, 2. udg. 2008) og Politikens bog om islam (2008). Det er bøger, der er præget af overblik, og som kom et stort behov i møde. Ikke mindst Det 
retfardige samfund. Om islam, muslimer og etik (2001), der udkom i året for terrorangrebet på USA og en nu stærkt ophedet politisk debat om islam i Danmark. Det var uundgåeligt, at Jørgen blev skydeskive for det nye værdipolitiske højre, som også kom til magten i de år, og den kristne Tidehvervs-bevægelse udgav en hel bog med kritik af hans bøger. Jørgen deltog pludselig i debatter, som også handlede om ham selv, lanceret af folk, som for det meste ikke havde noget større kendskab til Mellemøst- eller islamstudier, men stærke meninger om, hvordan de skulle bedrives. En af de grundopfattelser, Jørgen bragte til torvs, var en fast overbevisning om, at unge muslimer, der er vokset op i Danmark, er lige så danske som alle andre unge, hvad enten de er religiøse eller ej. Han kendte dem langt bedre end sine kritikere fra sin forskning og sin undervisning.

Heldigvis bød der sig en ny mulighed til: Jørgen blev udnævnt til direktør for det Danske Institut i Damaskus, en vidunderlig smuk købmandsgård i en gyde i det gamle Damaskus, bygget over det antikke romerske teater. Her tilbragte Jørgen og hans kone Kirsten fem år fra oktober 2001, i et smukt kontor med udsigt over gårdspladsen og fontænen. Det var en spændende tid i Syrien med politisk forandring på dagsordenen, med Golfkrig i nabolandet Irak og endnu en intifada i Palæstina rettet mod den fortsatte israelske besættelsesmagt. Der var mange aktiviteter på instituttet i disse år, med gæsteforskere og -kunstnere, udstillinger, koncerter og konferencer, og Jørgen var en dedikeret vært, som rakte bredt ud og fik alle til at føle sig velkomne - ikke mindst når han med begejstring fortalte danske rejsende om instituttets fascinerende historie. Også her fik han udgivet, blandt andet redigerede han bogen Youth and Youth Culture in the Contemporary Middle East (2005) i instituttets egen skriftrække.

Ironisk nok fik han også i Damaskus skrevet Islam set med danske øjne. Danskeres syn på islam gennem 1000 år (2004), den første oversigt af sin art. Den bog kom til at udstikke hans senere virke; man mærker fascinationen af forgængerne i faget på Københavns Universitet, og det er dem, som Jørgen i de sidste mange år har studeret og publiceret om: Frants Buhl (1850-1932), Johannes Pedersen (1883-1977) og ikke mindst Johannes $\emptyset$ strup (1867-1938), der 110 år før Jørgen havde vandret omkring i Damaskus basarer (og faktisk red hele vejen hjem til København på hesteryg). $\emptyset$ strup var en farverig person, der ganske som Jørgen nød at formidle sit fag både inden- og uden for universitets mure. Ganske som Buhl, Østrup, Løkkegaard og Pedersen har Jørgen Bæk Simonsen fortjent sin plads i fortællingen om danskernes syn på islam igennem 1000 år.

Festskriftets redaktion FANNIE AGERSCHOU-MADSEN MICHAEL IRVING JENSEN CLAUS VALLING PEDERSEN JAKOB SKOVGAARD-PETERSEN 